\title{
Effect of Climate Variability on Crop Income in Central Ethiopia
}

\author{
Arega Shumetie $^{1 *}$, Belay Kassa ${ }^{2}$, Degye Goshu ${ }^{3}$, Majaliwa Mwanjalolo ${ }^{4}$ \\ ${ }^{1}$ Department of Economics, College of Business and Economics, Haramaya University, Ethiopia \\ ${ }^{2}$ Pan African University, Africa Union, Addis Ababa, Ethiopia \\ ${ }^{3}$ Department of Agricultural Economics: College of Agriculture and Environmental Science. Haramaya University, Ethiopia \\ ${ }^{4}$ Geo Informatics and Climatic Sciences: College of Agriculture and Environmental Science. Makerere University, Uganda
}

\section{A R T ICLE INFO}

\section{Research Article}

Received 31 August 2017

Accepted 05 November 2017

\section{Keywords:}

Climate variability

Smallholder

Crop income

Rainfall

Temperature

\begin{tabular}{l}
${ }^{*}$ Corresponding Author: \\
\hline E-mail: ashueconomist@gmail.com
\end{tabular}

\begin{abstract}
A B S T R A C T
Ethiopian agriculture is a vulnerable sector from effects of climate variability. This study identified how strong is the effect of climate variability on smallholders' crop income in Central highlands and Arssi grain plough farming systems of the country. The unbalanced panel data (1994-2014) of the study collected for eight rounds analysed through fixed effect regression. The model result shows that successive increment of crop season rainfall keeping the temperature constant has negative and significant effect on households' crop income in the study area. The crop income responds similarly for temperature increment if the rainfall remains constant. Given this, simultaneous increment of the two climate related inputs has positive and significant effect on crop income. Other variables like flood, frost, storm, and rainfall inconsistency in the onset and cessation time affected households' crop income negatively and significantly. Similarly, draught power and human labour, which are critical inputs in the crop production of Ethiopian smallholders, have positive and significant effect on crop income as to the model result. Thus, this study recommended that there should be supplementing the rainfall through irrigation, check dam and other activities to have consistent water supply for the crop production that enable smallholders to collect better income. Additionally, negative effect of temperature increment should be curved through adopting long lasting strategies like afforestation.
\end{abstract}

DOI: https://doi.org/10.24925/turjaf.v5i12.1536-1543.1494

\section{Introduction}

Scientific findings from different directions of the world argued that land and sea surface temperatures are increasing because of greenhouse gases emission (IPCC, 2007), and will continue to warm unless there is human intervention to reduce. Global warming promotes floods, drought, hailstorm and other shocks that have devastating impact on the world economy (IPCC, 2014). There is steep rise in global temperature especially in the $21^{\text {st }}$ century (IPCC, 2012), which is one indicator of climate variability. This increment results in significant precipitation variation and severe moisture stress in some areas. Recently, there have been frequent extreme drought and heavy precipitation in some parts of the world.

Climate variability is affecting developed and developing nations differently, for instance the latter suffer from serious food shortage and starvation while developed ones face relatively simple problems (FAO, 2008). The nature dependent agriculture of developing nations shows significant variation and inconsistency as of rainfall and temperature variability. Majority of the chronically starved people of the world, whose livelihoods depend directly on the nature dependent agriculture, reside in rural areas of developing countries (FAO, 2009). Strong interaction of developing countries' agriculture with nature result in huge performance reduction in the entire economy if there is weather variation (Sara, 2012). Fischer et al. (2005) and Cline (2007), respectively forecasted that agricultural yields of developing countries will decline by $15 \%$ and $20 \%$ in 2080 due to climate variability. Similarly, Rosenberg et al. (2001) projected that African cereal production will decline by $2-3 \%$ in 2020, and this would result in significant crop income reduction. UNDP (2007) reported that climate variability and change could exacerbate income inequalities among countries. In some African countries net revenues from crops could fall by $90 \%$ in 2100 (IPCC, 2007).

Dell et al. (2008) showed that a $1^{\circ} \mathrm{C}$ temperature rise in a given year would result in $1.1 \%$ annual economic growth reduction for poor countries; this is because of widespread effects of high temperature on agricultural productivity. According to Schlenker and Lobell (2010) the significant yield decline in 2050 will cause huge crop income reduction nearly in all countries of Sub-Saharan 
Africa. If the current trend of warming continues, then vulnerability among the rural livelihood would be exacerbated (Arjan et al., 2011). Mathilde and Zaneta (2014) identified that climate variability should be perceived as an important source of risk for rural households in developing countries. Those suffering most are subsistence farmers, whose income is very low, and already in starvation and absolute poverty.

In Ethiopia climate variability is mainly manifested through rainfall inconsistency and temperature increment (Ethiopian National Meteorology Agency (NMA), 2007)). Major climate hazards observed in the country include drought, flood and diseases outbreak. Unfavourable rainfall and temperature conditions can have devastating effects on farm households if agriculture is purely dependent on rain (Paul et al., 2011), which means successive variability of them would have an overwhelming impact on smallholders' productivity. Vulnerability of Ethiopian smallholders would be severe due to their lower adaptation capacity and high dependency on nature based agriculture. Exposure to drought risk is high and coping capacities are limited due to lower income diversification (Arjan et al., 2011). These all would result in agriculture productivity and crop income variation.

Though there are few studies done before in connection with climate variability considering Ethiopian economy, but they took the national economic system as a sample rather than smallholders who suffer most from the problem. This study adopted panel data to examine effect of climate variability on smallholders' crop income in Central Highlands and Arssi Grain Plough farming systems of Ethiopia.

\section{Methodology}

Description of the Data Source and Sampling

Ethiopian Rural Household Survey (ERHS) was conducted for seven rounds by International Food Policy Research Institute (IFPRI), Centre for the Study of African Economies (CSAE) at Oxford University, Economics Department of Addis Ababa University and Ethiopia Development Research Institute (EDRI) from the four dominant regions (Tigrai, Amhara, Oromia and SNNP) of the country. The survey was started in 1989 when IFPRI team visited 450 households from seven villages in Central and Southern Ethiopia (Dercon and Hoddinot, 2004). The survey expanded to 15 villages and became well organized in 1994 so as to cover the main agro-climatic zones and farming systems of the country. The survey considered 1,477 households in 1994 and these households have been re-interviewed in the late 1994 as well as in 1995, 1997, 1999, 2004 and 2009 (Dercon and Hoddinot, 2004). Central highland area of the country accounts about $40 \%$ of the total population based on Central Statistics Agency (CSA) in 1994 and $56.4 \%$ sampling share of ERHS in 1994 survey (Dercon and Hoddinott, 2011). ERHS considered crop production systems as an important stratification base than administrative boundaries in selecting sample villages. Sampled smallholders were randomly selected from each village in order to have representative sample size. This research had 581 smallholders as a sample from the six villages in the two farming systems for one round survey in 2014 that enable to have eight round unbalanced panel data (Table 1).

Table 1 Agro-ecological zone and average rainfall of sample villages*

\begin{tabular}{l|llclc}
\hline \multicolumn{1}{c|}{ Village name } & Location & Main crops grown & Average rainfall & Agro-ecology & Sample household \\
\hline Yetmen & Gojjam & Teff, maize, wheat & 1241 & Moderate & 51 \\
D/Berhan & North Shoa & Wheat, barley, beans & 919 & Cold & 168 \\
Dinki & North Shoa & Teff, maize, sorghum & 1664 & Warm & 79 \\
Sirbana & Shoa & Teff, wheat, barley & 672 & Moderate & 82 \\
Tirurufe & South Shoa & Teff, wheat, barley & 812 & Moderate & 95 \\
Korodegaga & Arssi & Teff, maize, wheat & 874 & Warm & 106 \\
\hline
\end{tabular}

*Source: ERHS, 2009

\section{Type and Methods of Data Collection}

Both primary and secondary data were considered in this study, wherein the former ones collected from the six sample villages (Table 1). The data cover almost all features of smallholders like demographic, consumption, production, asset holding, purchases and sales, landholdings, livestock ownership and other aspects. The seven round data from 1994-2009 were collected from rural part of the country especially from high and midlands where mixed farming is practiced (crop production and animal husbandry). Each survey followed a similar format and contents covered in each round were similar so that it is easy to identify the sense of what can and cannot be done with these data. The eighth round data in 2014 take into account the recent circumstances of smallholders from each sample village through adopting the questionnaires used by the previous institutions to collect data in 2009. The study revisit all sampled households (581) in the six villages from central highland and Arssi grain plough farming systems to collect the last round data in 2014. Thus, the research had eight round unbalanced panel data on smallholder households in central highlands and Arssi grain plough farming systems of Ethiopia.

\section{Methods of Data Analysis}

Researches done before adopt Ricardian approach to assess effect of climate variability on rural household income. The approach argued that environmental factors affect production, costs and farmer's choice that result in net revenue change from each plot of land. Long-term net revenue accumulation determines land value. A key assumption to this approach is that land used for a given purpose is best used for that purpose. Land values in this model represent the present value of rents when land is used for its optimal purpose. Additionally, it assumes that 
both product and input markets function perfectly. Similarly, the approach assumed that climate changes are instantaneous and the economy adjusts to these changes completely, so that land prices reflect a long-run climatic equilibrium. Based on the approach each farmer wishes to maximize income subject to exogenous conditions. Effect of climate variability on farm households' economic wellbeing can be measured in gross value of production, cost, net value of production, or farm income (John, 2009). Di Falco (2011) implemented Ricardian analysis and used net revenues as a dependent variable. This can be particularly useful if produces of different crops aggregated to generate income. Nhemachena et al. (2010) considered net farm revenues to measure economic impact of climate change on African agricultural production systems. Thus, rural income from crop production can be formulated as:

$$
Y_{h r t}=\sum P_{i r t} Q_{i h t}\left(\mathrm{X}_{\mathrm{iht}}, L_{i h t}, \mathrm{H}_{\mathrm{iht}}, K_{i h t}, C_{i h t}\right)-\sum \mathrm{I}_{i t} \mathrm{X}_{i t}
$$

\section{Where:}

$\mathrm{Y}_{\text {hrt }}$ :Crop income (In terms of Birr) (Birr is the domestic currency unit) of household (h) in a specific village $(\mathrm{r})$ at time $\mathrm{t}$

$\mathrm{P}_{\text {irt }} \quad$ :Market price of crop $\mathrm{i}$ in each village (r) at time t. The research assumed that households in each village have common market where prices are the same for households within the village.

Q iht :Marketable quantities of crop i for household (h) at time t,

$\mathrm{X}_{\text {iht }} \quad$ :A vector of inputs like seeds, fertilizer, and pesticides used by household (h) for crop $i$.

$\mathrm{L}_{\text {iht }} \quad$ :Human labour input budgeted by household (h) for producing crop $\mathrm{i}$ at time $\mathrm{t}$

$\mathrm{H}_{\text {iht }}$ :Demographic variables budgeted for producing crop $\mathrm{i}$ at time $\mathrm{t}$

$\mathrm{K}_{\mathrm{iht}} \quad$ :Capital input budgeted by household (h) for the producing crop $\mathrm{i}$ at time $\mathrm{t}$

$\mathrm{C}_{\mathrm{it}}$ :Climate related variables that affect crop i at time $\mathrm{t}$

$\mathrm{I}_{\mathrm{it}} \quad$ :Individual price for input $\mathrm{i}$ at time $\mathrm{t}$

Based on the above equation marketed quantity is an endogenous variable that is directly affected by vector of inputs, household related variables, climatic and other factors.

$Q_{\text {iht }}=F\left(X_{\text {iht }}, L_{\text {iht }}, H_{\text {iht }}, K_{\text {iht }}, C_{\text {it }}\right)$

Equation 2 implies that climate variations have a direct effect on marketable quantity and consequently have an indirect effect on income. Since temperature and rainfall variability are likely to affect crop yields and the ultimate effect would be on revenue of smallholders' (IPCC, 2001). If a farmer chooses the crop that provides the highest net income and manage each endogenous input to maximize the income, then income will be just a function of exogenous variables only (Mendelsohn et al., 1994).

$\mathrm{Y}_{h r t}=\mathrm{F}\left(\mathrm{P}_{\mathrm{irt}}, \mathrm{X}_{\mathrm{iht}}, \mathrm{L}_{\mathrm{iht}}, \mathrm{H}_{\mathrm{iht}}, \mathrm{K}_{\mathrm{iht}}, \mathrm{C}_{\mathrm{it}}, \mathrm{I}_{\mathrm{iht}}\right)$
Smallholder's crop income variability is the result of change in one of those variables or simultaneous change in two or more of them at once. Price volatility may increase in the future, since effects of climate variability are likely to increase uncertainty and instability of food crop production in tropical regions (Blein and Longo, 2009). Additionally, households' income may be affected by the available inputs and other demographic factors, thus equation 3 would be rewritten in the following form.

$\mathrm{Y}_{h r t}=\mathrm{F}\left(\mathrm{P}_{i r t}, \mathrm{X}_{i h t}, \mathrm{~L}_{i h t}, \mathrm{H}_{i h t}, \mathrm{~K}_{i h t}, \mathrm{C}_{i t}, \mathrm{I}_{i h t}, \mathrm{D}_{h r t}\right)$

$\mathrm{D}_{\text {hrt }} \quad$ :Demographic related shocks for household (h) at a specific time $t$.

Deressa (2006) and Jain (2006) considered net farm revenue to assess economic impact of climate change. Similarly, this research approximated smallholder's income by gross margin from crop production only and reformulated the above equation as:

$\ln Y_{\mathrm{hrt}}=\theta_{0}+\theta_{1} \ln \mathrm{P}_{\mathrm{irt}}+\theta_{2} \operatorname{lnL} \mathrm{Lht}_{\mathrm{iht}}+\theta_{3} \ln \mathrm{H}_{\mathrm{iht}}+\theta_{4} \operatorname{ln\mathrm {nK}_{\mathrm {iht}}}+$
$\theta_{5} \operatorname{lnC} \mathrm{C}_{\mathrm{it}}+\theta_{6} \operatorname{lnI} \mathrm{I}_{\mathrm{iht}}+\theta_{7} \operatorname{lnD}_{\mathrm{hrt}}+\mu_{\mathrm{i}}+\varepsilon_{\mathrm{it}}$

The study considered cropping season rainfall and temperature variation as an approximation to climate variability, which may take the right hand share in affecting the dependent variable. Extreme shocks such as droughts, flooding and frost severely affect smallholders' crop production were included in the regression. Considering all these the above equation can be transformed to the following form:

$\ln \mathrm{Y}_{\mathrm{hrt}}=\theta_{0}+\theta_{1} \ln \mathrm{P}_{\mathrm{irt}}+\theta_{2} \ln \mathrm{L}_{\mathrm{iht}}+\theta_{3} \ln \mathrm{H}_{\mathrm{iht}}+\theta_{4} \ln \mathrm{K}_{\mathrm{iht}}+$ $\theta_{5} \operatorname{lnR}_{\mathrm{rt}}+\theta_{6} \operatorname{lnT}_{\mathrm{rt}}^{0}+\theta_{7} \operatorname{lnI}_{\mathrm{iht}}+\theta_{8} \ln S_{\mathrm{rt}}+\theta_{9} \ln \mathrm{D}_{\mathrm{hrt}}+\mu_{\mathrm{i}}+\varepsilon_{\mathrm{it}}$

$\mathrm{R}_{\mathrm{rt}}$ and $\mathrm{T}_{\mathrm{rt}}^{0}$ connote cropping season rainfall and temperature level in each village $r$ at time $t$.

$S_{\text {rt }}$ refers to shocks resulted from climate variability that happened in those villages at time $t$. This variable is dummy type and it may be common for each household within a village.

\section{Results and Discussion}

Income of small-scale farmers in developing countries would decline sharply if their crop production fails since the sub-sector is their main source of income. Climate extreme events may affect availability of certain food products, which may influence price that could have an effect on income earning opportunities. There may be short-term fluctuation in smallholder's income linked to yield variation, which may be influenced by climate change, among others (Thompsen and Metz, 1998). Drought was the main causal factor that triggers poverty (Yue et al., 2013). Production variability due to regional weather events like major drought causes farmers to receive a highly volatile net income from crop production (Susanne, 2012). These all imply that climate variability has strong effect on farmers' livelihood if they are purely dependent on farming. Given this, descriptive and econometrics results of this study are discussed below. 
Crop Income and Rainfall Trend in the Two Farming Systems

Crop income in the two sample farming systems was very low before 2004 production year, which may be due to either production or price level reduction wherein both of them were lower than the recent level. In 1994a (There were two round data collection in 1994 and 1994a refers the first round) and 1994b (Second round data collection in 1994) households in Arssi grain plough farming system collected better crop income than those in central highlands. Crop income of this farming system exhibited better improvement starting from 1997. Though there was slow increment in crop income of the two farming systems after 1995, but the level was better in Arssi grain plough until 2009. However, households' crop income in this farming system decreased in 2014 that may be related to crop production reduction due to inconsistent rainfall.

Villages that are near to the central market in the two farming systems have better and continuously increasing crop income than others that are distantly located. The world level crop price increment since 2008 may be one reason for the sharp income increment for households in two farming systems in 2009 and 2014 (Table 2). The overall average income of households in central highland was 1893.69 with a standard error of 1068.15 and Arssi grain plough had 1575.56 with a standard error of 522.01 . There was significant difference (P-value of 0.044) in it for households in the two farming systems.

Bartlett's test for variance equality reveals that there is statistically significant $(\mathrm{P}$-value $=0.000$ and $\chi 2=$ 494.99) difference in crop income variance of the two farming sytems for the sample production years. Table 2 shows that there was consistent difference in households' income in the two farming systems as per the t-test.

Cropping season rainfall of each station showed strong variation in each sample production year (Figure 1). The negative coefficient of the two trend lines indicates that there is continuous reduction in the cropping season rainfall in the two farming systems. Though there was subsequent reduction in rainfall starting from 1999 production year, the crop income exhibited continuous increment in central highland farming system. At the medium level rainfall of 1995 and 2004 crop income was relatively better in which there was positive interaction between them for those years.

Table 2 Yearly crop income of smallholders in the two farming systems

\begin{tabular}{l|cccc}
\hline \multicolumn{1}{c|}{ Year } & Central highland & Arsigrain plough & Combined mean & $\mathrm{t}$-value \\
\hline $1994 \mathrm{a}$ & 469.96 & 685.51 & 541.81 & $-2.62^{* *}$ \\
$1994 \mathrm{~b}$ & 413.70 & 802.41 & 543.28 & $-8.47^{* * *}$ \\
1995 & 450.37 & 502.00 & 467.58 & $-4.16^{* * *}$ \\
1997 & 670.85 & 1070.81 & 804.17 & $-5.76^{* * *}$ \\
1999 & 635.15 & 985.59 & 751.96 & $-4.30^{* * *}$ \\
2004 & 784.58 & 1215.61 & 928.26 & $-4.63^{* * *}$ \\
2009 & 2908.29 & 3300.00 & 3104.15 & $-4.65^{* * *}$ \\
2014 & 5800.00 & 3600.00 & 4700.00 & $6.10^{* * *}$ \\
Overall mean & 1258.98 & 1521.45 & 1349.49 & \\
Overall Std. Dev. & 4802.05 & 2861.49 & 4236.06 & \\
Between Std. Dev & 2696.82 & 1382.86 & 2339.58 & 3762.82 \\
Within Std. Dev. & 4259.85 & 2566.97 & & \\
\hline
\end{tabular}

*** and ** indicate 1\% and 5\% level of significance, respectively, Source: ERHS (1994a-2009) and own survey, 2014

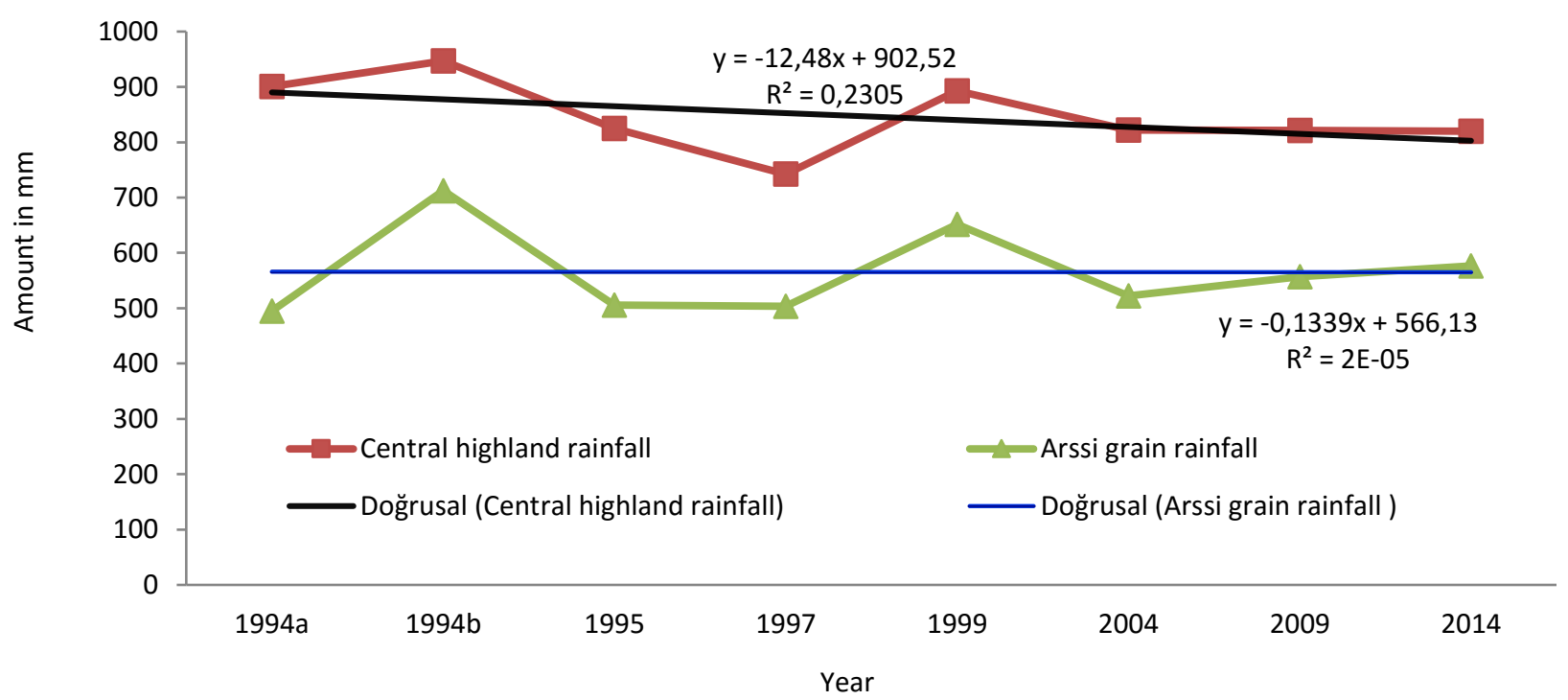

Figure 1 Cropping season rainfall trend in the two farming systems

Source: Ethiopian national meteorology agency, 2015 
Average cropping season rainfall of the two farming systems showed similar trend throughout sampled years. This implies that ups and downs of rainfall in the two farming systems happed at the same production years. However, rainfall of the two farming systems was lower in 1997 production year than years both before and after, but the crop income was better. There was lower crop income collected by sample households in 1995 wherein the rainfall was also the lowest. Accordingly, farmers received a better income when rainfall level was lower in 1995, 1997 and 2004. Higher rainfall level of 1994b and 1999 production years correlated with lower crop income (Table 2) as compared to others like 1997 and 2004. Cropping season rainfall level of 1995 and 2009 was relatively at similar level but there was sharp increment in crop income in the latter production year that may be due to crop price increment. This logic of price and climate variability can be strengthened by considering 1999 production year on which crop income was better than 2004. According to Table 2 and figure 1, there is inverse relationship between cropping season rainfall and crop income for many of the sample production years.

The cropping season temperature in the two farming systems exhibited that it is increasing having positive coefficient on the trend equation. Even if Arssi grain plough has higher temperature than central highland farming system, but the rate of change is higher for the latter one. The successive increment in cropping temperature ought to be critical problem for smallholders to collect the potential crop income level.

\section{Model Diagnostic Test}

Crop production variation due to weather variability would finally result in significant net income variation from the sub-sector (Susanne, 2012). Climate variability has strong effect on smallholders' income if crop production is the sole source. This research assumed that climate variability has no fixed effect like demographic and idiosyncratic factors on smallholder's crop income. Random effects specification provides consistent estimators in estimating time invariant variables (Debarsy, 2012). The choice between fixed and random effect model of estimating the panel data dependence on different circumstances like the way of data collection, type of population from which samples drawn and purpose of analysis (Franco, 2001). The author argued that if an individual has an interest in assessing specific difference among small number of regions or countries, it is better to use fixed effect model. Given those, ordinary means of identifying method of regressing panel data, this research conducted the required diagnostic tests of identifying the appropriate model of analysing the unbalanced panel data.

The Breusch and Pagan test of identifying between random effect and pooled OLS shows that there is significant evidence $(\mathrm{P}$-value $=0.000$ ) to accept the former model of regression. After rejecting pooled OLS, the research just proceed to the next test, Hausman specification test, to identify between random and fixed effect. If the null hypothesis, "the time invariant individual effects are uncorrelated with other regressors", was accepted then the random effect model would be preferred against the alternative, fixed effect. The model selection test in Table 4 considered climate variability elements as an explanatory variables verified that fixed effect is the right model. The test result confirmed that time invariant covariates correlated with the other explanatories and there was no difference in income based on household related time invariant dummies.

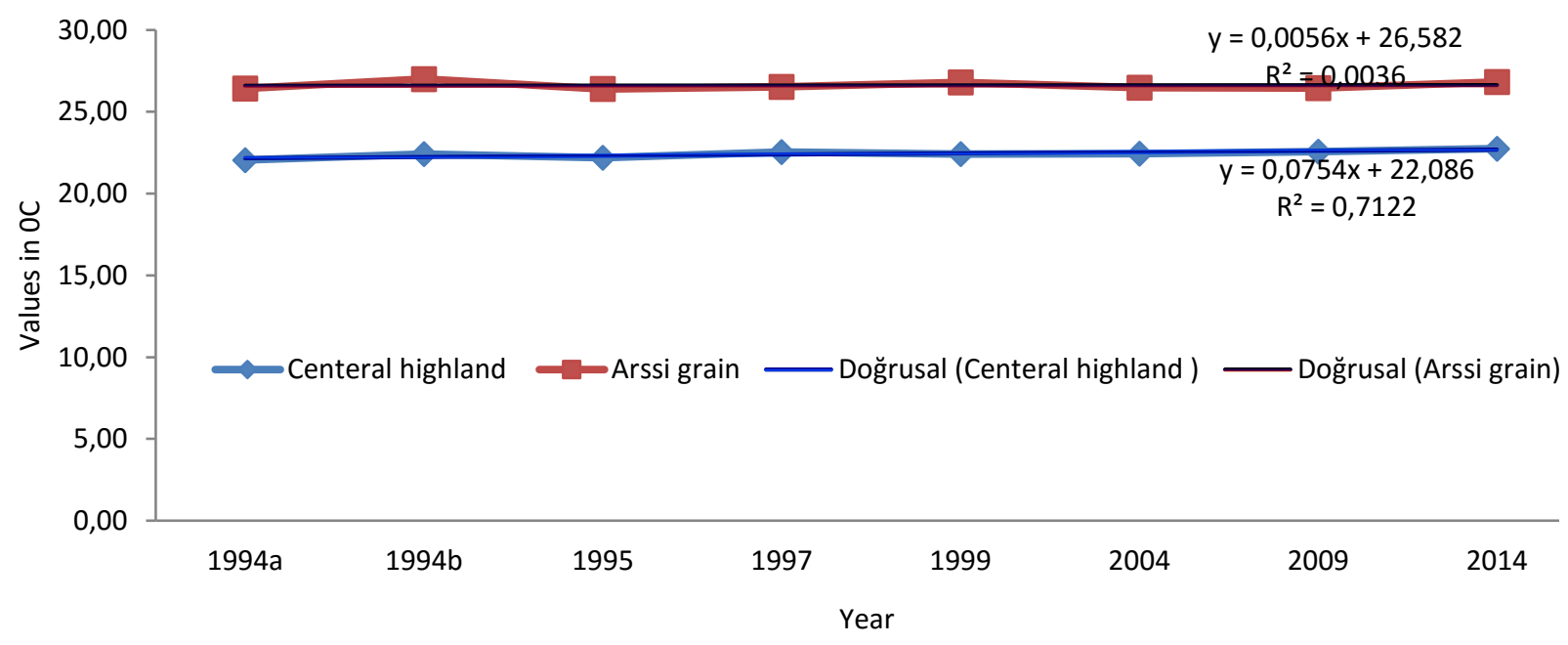

Figure 2 Cropping season temperature trend in the two farming systems Source: Ethiopian national meteorology agency, 2015

Table 3 Breusch and Pagan LM test

\begin{tabular}{|c|c|c|c|}
\hline Type of variable & Coefficient & Standard error & P-value \\
\hline Ln Crop income & 7.264 & 2.695 & \\
\hline Overall error component (e) & 4.600 & 2.144 & 0.000 \\
\hline Fixed- or random-error component $(u)$ & 1.090 & 1.044 & \\
\hline
\end{tabular}


Table 4 Hausman test result for fixed and random effect model selection

\begin{tabular}{|c|c|c|c|c|}
\hline \multirow{2}{*}{ Variable } & \multicolumn{2}{|c|}{ Coefficient } & \multirow{2}{*}{$\begin{array}{l}\text { Difference } \\
\text { (FE- RE) }\end{array}$} & \multirow{2}{*}{$\begin{array}{l}\text { sqrt(diag(V_FE } \\
\text { V_RE)) stan.err }\end{array}$} \\
\hline & Fixed (FE) & Random(RE) & & \\
\hline Ln Rain & 32.914 & -4.873 & 37.787 & 3.560 \\
\hline Ln Temperature & 85.612 & -1.787 & 87.399 & 8.695 \\
\hline Ln Rain X To & -10.731 & 1.365 & -12.095 & 1.138 \\
\hline Harvest time rain & -0.518 & -0.533 & 0.016 & 0.018 \\
\hline Growing time rain & 0.748 & 0.891 & -0.143 & 0.018 \\
\hline \multirow[t]{2}{*}{ Summer rain onset } & 0.308 & 0.227 & 0.081 & 0.015 \\
\hline & 195.19 & P-value & \multicolumn{2}{|c|}{0.000 accept fixed effect } \\
\hline
\end{tabular}

Ln represents natural logarithm

Table 5 Effect of climate variability on crop income

\begin{tabular}{|c|c|c|c|}
\hline Description & Coefficients & \multicolumn{2}{|c|}{ Robust Standard error } \\
\hline ln Rainfall & $-8.323 * * *$ & \multicolumn{2}{|l|}{1.014} \\
\hline ln Temperature & $-10.514 * * *$ & \multicolumn{2}{|l|}{1.211} \\
\hline ln (Rain X Temperature) & $2.466 * * *$ & \multicolumn{2}{|l|}{0.302} \\
\hline Shocks & $-0.243 * * *$ & \multicolumn{2}{|l|}{0.066} \\
\hline Idiosyncratic shocks & $-0.173 * * *$ & \multicolumn{2}{|l|}{0.065} \\
\hline $\ln$ TLU & $0.342 * *$ & \multicolumn{2}{|l|}{0.150} \\
\hline Pests & $-0.154 *$ & \multicolumn{2}{|l|}{0.082} \\
\hline Rain harvest time & $-0.145^{* *}$ & \multicolumn{2}{|l|}{0.072} \\
\hline Enough rain at beginning & $0.589 * * *$ & \multicolumn{2}{|l|}{0.080} \\
\hline Summer rain on time & -0.038 & \multicolumn{2}{|l|}{0.069} \\
\hline Off/non-farm activities & $-0.309 * * *$ & \multicolumn{2}{|l|}{0.068} \\
\hline Save account & $0.583 * * *$ & \multicolumn{2}{|l|}{0.083} \\
\hline Crop residue & $1.253 * * *$ & \multicolumn{2}{|l|}{0.097} \\
\hline ln Household size & $-0.580 * * *$ & \multicolumn{2}{|l|}{0.114} \\
\hline In Draught power & $0.343 * * *$ & \multicolumn{2}{|l|}{0.073} \\
\hline ln Cropland & $0.191 * * *$ & \multicolumn{2}{|l|}{0.032} \\
\hline Constant & $42.236^{* * *}$ & \multicolumn{2}{|l|}{4.115} \\
\hline Sigma_u & 1.360 & Prob $>$ F & 0.000 \\
\hline Sigma_e & 1.942 & Corr(u_i, Xb) & 0.0746 \\
\hline $\operatorname{Rho}(\rho)$ & \multicolumn{3}{|c|}{0.329 (fraction of variance due to $u_{-} \mathrm{i}$ ) } \\
\hline $\mathrm{R}^{2}$-within & \multicolumn{3}{|c|}{0.235} \\
\hline $\mathrm{R}^{2}$-between & \multicolumn{3}{|c|}{0.439} \\
\hline $\mathrm{R}^{2}$-overall & \multicolumn{3}{|c|}{0.313} \\
\hline
\end{tabular}

$* * *, * *$ and $*$ referes $1 \%, 5 \%$ and $10 \%$ level of significance, respectively, Ln represents natural logarithm

\section{Regression Result and Discussion}

Table 5 shows that more than $32.91 \%$ of the variation in the dependent variable was due to panel effect. The model result revealed that rainfall and temperature increment affected smallholders' crop income significantly and negatively as well. Interaction between the two dominant climate variability elements and crop income was negative in the two farming systems of Ethiopia. This interaction indicated that partial effect of either rainfall or temperature was negative, which was a finding similar to Félix and Romuald (2014). Those authors argued that changing rainfall pattern is a source of uncertainty and agricultural income fluctuation, which result in significant economic growth reduction for rainfed production dependent developing countries. Ajay and Pritee (2013) identified positive and statistically significant interaction between rainfall and agricultural produce value, which is a finding contrary to Table 5. Their finding implied that rainfall increment is beneficial for increasing produce value due to lower production. This circumstance could not be acceptable for Ethiopian smallholders who have not marketable amount to collect benefits of crop price increment. A $1 \%$ cropping season temperature or rainfall increment respectively resulted in $10.51 \%$ and $8.32 \%$ crop income reduction for a given household. The covariate generated based on interaction of rainfall and temperature had positive and significant effect on smallholders' crop income. Thus, climate variability had negative effect on smallholders' crop income, which may be due to its strong effect on the marketable amount.

Other variables such as flood, frost and storm, which have a devastating effect on crop production, affected smallholders' crop income negatively. Covariates related to rainfall inconsistency such as timely onset of summer and enough rain at sowing time significantly affected smallholders' crop income. Availability of sufficient rainfall at the beginning, and consistent supply throughout crop growing season may increase the marketable amount of crops through improving the quantity produced. Earlier works conduced in Africa were in support of Table 5, for instance Ole (2011) found that rain-fed agriculture income reduction largely attributed to rainfall insufficiency (quantity and distribution) in many west African countries. Kaul and Ram (2009) argued that excessive rain and extreme temperature variation 
adversely affected crop productivity and thereby influence income of the farming families. Some extreme events are associated with very poor harvests of cash crops, which severely affect income of the farming sector (Marc et al., 2013).

The other variable sourced from temperature and rainfall inconsistency was pest infestation, which strongly affected crop income $(0.15 \%$ reduction). Pest commonly known as faki highly affect crop production of households in central highlands and crops planted in areas infested with this pest produce nothing (Dercon and Hoddinott, 2011). Drought was main causal factor triggering poverty through changing the crop production (Yue et al., 2013). Smallholders across the tropics already faced numerous risks including pest and disease outbreaks, extreme weather events and market shocks that frequently reduced household agricultural production and income (Celia et al., 2014).

Agricultural labor and mechanization negatively affect the produce value in India (Ajay and Pritee, 2013) since there would be exccess production but the overall crop income effect is positive through increasing marketable amount. Similarly, draught power allocated for agriculture, which are critical inputs in Ethiopian crop production, had positive and significant effect on crop income (Table 5). For a given smallholder $1 \%$ increment in the draught power would increase the crop income by $0.34 \%$. Household member's participation in off-farm activities had negative and significant effect on crop income, which was a finding similar to Tesfaye et al. (2015) "each additional earning from off-farm work has negative and statistically significant effect on marketed surplus". The negative effect of off-farm activity participation may be due to labour competition between crop production and other activities that would result in crop produce reduction. Easy accessing credit and saving facilities significant and positive affect households' crop income in the study area. Smallholders' capacity to purchase agricultural inputs and the crop production could be enhanced if they have access to credit.

The large family size in rural Nigeria had negative and significant effect on income and savings, and aggravates poverty (Omideyi, 1988). Similarly, Tessema (2015) argued that number of dependency ratio significantly reduced rural household's income. Smallholders' family size has two contradictory effects on crop income: the consumption effect that reduced crop income due to large home consumption. Contrary to this, family size has production effect that increases crop income through producing excess marketable amount. Thus, overall effect of family size increment always depends on magnitude of the two effects within the household. Based on Table 5 the variable had negative effect on crop income collection, which means the consumption effect outweighs the production in the study area. Negative interaction of family size and crop income implied that large family size had more of consumption effect but not production for smallholders in the two farming systems of Ethiopia. The marketable amount that directly increased crop income could increase if a household had small family size. The reduction in household's consumption demand could shift produces to be marketable type that guarantee better crop income for the household.

\section{Conclusions and Recommendations}

The study used unbalanced panel data and employed fixed effect model of data analysis to examine effect of climate variability on smallholders' crop income in central highland and Arssi grain plough farming systems of Ethiopia.

Successive individual increment in either cropping season rainfall or temperature adversely affects smallholders' crop income in the two farming systems. Similarly, inconsistency in rainfall amount at different stages the crop production has significant and negative effect on crop income. The on-going climate variability has also indirect effects like creating favourable condition for pest and disease outbreak, which have significant and negative effect on crop income as to the model result.

Simultaneous increment of cropping season rainfall and temperature has positive effect on smallholders' crop income, implies that counterbalance effect of rainfall on temperature increment is strong in the two farming systems.

Smallholders' family size affects the crop income negatively that may be because of lower marketable amount after the larger household's consumption demand.

Factors of production including access to saving, draught power and cropland, which enhance smallholder's crop productivity, have positive and significant effect on crop income of the farm households in the study area.

Thus, based on the above findings the research forward the following recommendations:

- Co-ordinated efforts should be there to curb the rainfall inconsistency problems or else extreme starvation and poverty that happen occasionally will be frequent within expanded area coverage.

- The concerned party should be ready and aware to support smallholders to have consistent moisture supply through irrigation and water harvesting to reduce crop income variability.

- To reduce the external effect of chemicals on livestock and beehives of rural farmers' biological way of protecting outbreak of pests and disease should be adopted. Similarly, the biological methods could be affordable for smallholders.

- Awareness of households in the two farming systems should be enhanced to increase their participation in off-farm activities and crop residue collection.

- The on-going climate variability problem should be one issue in formulating micro and macroeconomic policies to have sustainable income for smallholders.

\section{References}

Ajay K, Pritee S. 2013. Impact of Climate Variation on Agricultural Productivity and Food Security in Rural India Discussion Paper No. 2013-43: http://www.economicsejournal.org/economics/ discussionpapers/2013-43

Arjan R, Mark de B, Minna K, Vincent L, Nico P. 2011. Adaptation to Climate Variability: the role of past experience and institutions. The Netherlands. 
Blein R, Longo R. 2009. Food Price Volatility-how to help smallholder farmers manage risk and uncertainty? Discussion paper prepared for the Round Table organized during the Thirty-second session of IFAD's Governing Council.

Celia AH, Zo Lalaina R, Nalini RS, Radhika D, Hery R, Rivo HR, Haingo R, James LM. 2014. Extreme vulnerability of smallholder farmers to agricultural risks and climate change in Madagascar. Philosophical Transaction of the Royal Society $\begin{array}{llll}\text { Biological } & \text { Science, } & 369 \text { : } & 20130089\end{array}$ http://dx.doi.org/10.1098/rstb.2013.0089

Cline W. 2007. Global Warming and Agriculture: Impact estimates by country. Washington, DC: Peterson Institute for International Economics. USA.

Debarsy N. 2012. The Mundlak approach in the spatial Durbin panel data model. Spatial Economic Analysis, 7: 109-131

Dell M, Jones BF, Olken BA. 2008. Climate Change and Economic Growth: Evidence from the Last Half Century. Working Paper 14132, NBER Working Paper Series, National Bureau of Economic Research

Dercon S, Hoddinott J. 2004. The Ethiopian Rural Household Surveys: Introduction. International Food Policy Research Institute. Addis Ababa: Ethiopia.

Dercon S, Hoddinott J. 2011. The Ethiopian Rural Household Surveys 1989-2009: Introduction. International Food Policy Research Institute. Addis Ababa: Ethiopia.

Deressa T.T. 2006. Measuring the Economic Impact of Climate Change on Ethiopian Agriculture: Ricardian approach: Centre for Environmental Economics and Policy in Africa -CEEPA, Discussion Paper No. 25: University of Pretoria.

Di Falco S, Mahmud Y, Gunnar K, Claudia R. 2011. Evidence from Agricultural Profits and Random Fluctuations of Weather: MIT Joint Program on the Science and Policy of Global Change. website:http://MIT.EDU/global change.

FAO (Food and Agriculture Organization). 2008. The State of Food Insecurity in the World. Food and Agriculture Organization of the United Nations, Rome, Italy.

FAO (Food and Agriculture Organization). 2009. Food Security and Agricultural Mitigation in Developing Countries: Options for Capturing Synergies. Rome, Italy.

Félix B, Romuald KS. 2014. Climatic Variability and Food Security in Developing Countries. Serie etudes et documents du cerdi. Clermont ferrand -France.

Fischer G, Shah M, Tubiello FN, vanVelthuizen H. 2005. SocioEconomic and Climate Change Impacts on Agriculture: an integrated assessment, 1990-2080. Philos.T. Roy. Soc. B, 360, 2067-2083.

IPCC (Intergovernmental Panel on Climate Change). 2001. Climate Change: Impacts, Adaptation and Vulnerability. Report of the Working Group II. Cambridge: Cambridge University Press.

IPCC (Intergovernmental Panel on Climate Change). 2007. Agriculture in Climate Change 2007: Mitigation. Working Group III Contribution to the Fourth Assessment Report of the IPCC. Cambridge: Cambridge University Press.

IPCC (Intergovernmental Panel on Climate Change). 2012. Managing the Risks of Extreme Events and Disasters to Advance Climate Change Adaptation. Cambridge University Press, England, pp. 582.
IPCC (Intergovernmental Panel on Climate Change). 2014. Impacts, Adaptation, and Vulnerability. Cambridge: Cambridge University Press.

John M.A. 2009. Agriculture and the Food System: Adaptation to Climate Change. An initiative of the climate policy program at RFF. Montana State University.www.rff.org/adaptation.

Kaul S, Ram G. 2009. Impact of global warming on production of sorghum in India (special issue: sustainable agriculture in the context of climate change), Agricultural Situation in India 66 (5):253-256.

Marc M, Safietou S, Wolfram L. 2013. Impact of changing seasonal rainfall patterns on rainy-season crop production in the Guinea Savannah of West Africa

Mathilde M, Zaneta K. 2014. Climate Variability and Migration: Evidence from Tanzania. Fondation pour les études et recherchessur le développement international. Development policy working paper.

Mendelsohn R, Nordhaus W, Shaw D. 1994. The Impact of Global Warming on Agriculture: A Ricardian Analysis. American Economic Review; 84:753-71.

Nhemachena C, Hassan R, Kurukulasuriya P. 2010. Considered net farm revenues Measuring the Economic Impact Of Climate Change On African Agricultural Production Systems. Climate Change Economics, Vol. 1, No. 1 (2010) 33-55.

Omideyi AK. 1988. Family size and productivity of rural households in Nigeria. https://www.ncbi.nlm.nih.gov/pubmed/ 12315558

Ole M, Cheikh M, Anette R, Lorenzo G, Eric FL, Sarah D, Malicki Z, Kjeld R, Drissa D, Bruno B, Ibrahim BM, Awa D, Jonas ØN, Inge S. 2011. Adaptation strategies and climate vulnerability in the Sudano-Sahelian region of West Africa. Published online in Wiley Online Library: Atmos. Sci. Let.12: 104-108.

Paul AL, Fisher M, Weber B. 2011. Do Rainfall Conditions Push or Pull Rural Migrants? Evidence from Malawi. Journal of Agricultural Economics 43 (2012) 191-204

Tesfaye BW, Thomas H, Yves S. 2015. Effect of off-farm income on smallholder commercialization: Panel evidence from rural households in Ethiopia. International conference of agricultural economists. Agriculture in an interconnected world.

Sara L. 2012. Climate Change, Weather Variability and Food Consumption: A Multidisciplinary Study of Rural Uganda. Catholic University of the Sacred Heart. Via Emilia Parmense 84, 29122 Piacenza, Italy.

Schlenker W, Lobell D. 2010. Robust Negative Impacts of Climate Change on African Agriculture, Environment Research Letters.

Susanne U. 2012. The impact of increasing rice and maize prices on household income in north western Vietnam. Scientific world. University of Hohenheim Stuttgart, Germany.

UNDP (United Nations Development Program). 2007. Climate Shocks: Risk and Vulnerability in an Unequal World. Human Development Report 2007/2008. Fighting Climate Change: Human Solidarity in a Divided World. New York,. Palgrave Macmillan: 73-107

Yue L, Conway D, Yanjuan W, Qingzhu G, Rothausen S, Wei X, Hui J, Erda L. 2013. Rural livelihoods and climate variability in Ningxia, Northwest China. Open access at Springerlink.com. Climatic Change 119:891-904.doi 10.1007/s10584-013-0765-9). 